

\section{Developing Educational Game for Collaborative Learning}

\author{
Aprilia Ratna Christanti \\ Game Technology Program, \\ Information Systems Department, \\ Faculty of Computer Science, \\ Soegijapranata Catholic University \\ Semarang, Indonesia \\ 13070029@student.unika.ac.id
}

\author{
Ridwan Sanjaya \\ Information Systems Department, \\ Faculty of Computer Science, \\ Soegijapranata Catholic University \\ Semarang, Indonesia \\ ridwan@unika.ac.id
}

\author{
Cecilia Titiek Murniati \\ English Department, \\ Faculty of Language and Arts, \\ Soegijapranata Catholic University \\ Semarang, Indonesia \\ c_murniati@unika.ac.id
}

\begin{abstract}
Nowadays, conventional methods of learning are no longer enthused by students, because a one-way teaching method makes students easily bored. Collaborative learning methods are used to make students more interested in learning and encourage students to actively contribute to the classroom session. One of the benefits of collaborative learning as a learning method is that it allows each student in a group to actively contribute and share their ideas. An example of collaborative learning implementation in the classroom is computer-supported collaborative learning (CSCL). CSCL is a type of collaborative learning technique in which students can learn a subject matter with their peers using computers. Such strategies could be implemented in the form of digital games to make the collaborative learning methods more attractive and interactive. This paper attempts to investigate students' perception toward the collaborative task of designing a game in a language classroom. Overall, the findings suggest that students showed positive attitude towards the task because it allowed them to understand the subject matter better.
\end{abstract}

Keywords - collaborative learning; digital game; game design; educational game; mobile application

\section{INTRODUCTION}

Science plays a vital role in developing social and economic status worldwide [1]. The advancement of science and technology brings the global society to prosperity. The strategy to master advanced science and technology is to educate people to become excellent human resources that can compete internationally[2].

Indonesian government enacted Law No. 20 of 2003 on National Education System, therein described the meaning of education in paragraph 1 of Article 1, which states "Education means a conscious and well-planned effort in creating a learning environment and learning process so that students will be able to develop their full potential for acquiring spiritual and religious strengths, develop selfcontrol, personality, intelligence, morals, noble character and skills that one needs for him/herself, for the community, for the nation, and for the State." [3]. The law clearly encourages students to actively develop their potential in order to better understand what they learn. The teaching and learning strategies should be well designed in order to create well rounded students.

In Indonesia, the teaching and learning approach, especially in K-12 settings, is mostly based on grades. Teachers and parents pay more attention to grades instead of the actual learning process. Students learn course contents by rote memorization[4]. 2013 educational curriculum was designed as an attempt to change the educational paradigm, but it was not popular among K-12 teachers and policy makers. In higher education institutions, however, the teaching and learning paradigm is slightly different from that in K-12 education because teachers have more freedom to determine the most appropriate teaching strategies that can sharpen students' critical thinking skills.

Many university teachers adopt active learning strategies so that students become more creative, innovative, and engaged. Some of the methods that teachers often use are collaborative and cooperative learning. Cooperative learning refers to a teaching method in which students divide tasks among group members, whereas collaborative learning is a learning method in which each student contributes their skills and strengths to accomplish a task together. These methods can be combined to obtain the best learning experience. Teachers use various tools including digital media, which was known as computer-supported collaborative learning (CSCL). CSCL is a type of collaborative learning technique in which students can learn a subject matter with their peers using computers [5].

With CSCL, teachers can also create digital games to increase student engagement and attract students' interest. Digital games can be used not only for entertainment, but also as an interactive, unique, and effective learning media [6]. Salen claims that the use of games in education is acceptable as long as the games are "rich with data". A good educational game is one that has a lot of instructions for players such as how to play the game, what players should do to complete the game, how they get points or bonuses, and so on [7]. 
The growth of computer technology and its increasing number of users, particularly for mobile devices or smartphones worldwide, has been predicted to exceed two billion in 2016. The results of the survey firm eMarketer showed that smartphone users increased by $12.6 \%$ from 2015, from 1.91 billion to 2,16 billion [8]. This has created greater opportunities for creative industries based on games. Anyone who has an interest in computer games, including teachers and lecturers, has the opportunity to be involved in the development of educational games. Teachers have the knowledge and experience, based on their respective fields of study, which they can use to develop the content of educational games [9].

Recent literature also indicates that games are used mostly by users of gadgets or mobile devices; thereby educational games have a potential to be incorporated as a media of collaborative learning methods [10]. Games can be used and integrated in the teaching and learning process. However, teachers need to select the most appropriate games if depending on students' technological comfort level, students' interest and abilities, subject matters, and goals of the course. [11].

Meta-analysis studies on the effectiveness of serious games for learning reveal mixed results. However, serious games do have positive effects on motivation and class engagement [12]. Piirainen-Marsh and Taino (2009) examined how their research participants engaged and interacted when playing the game. They found that games provided ample interactional opportunities when they played the games. Game based learning approach, in addition, can promote students problem solving skills and increase learning motivation [13].

Previous studies on serious games focused more on the ready to use games. The participants were tested as the users of games. In this study, however, the researchers would like to use games as a tool to work collaboratively. In other words, the participants in this study were asked to design a game and create activities and exercises in a collaborative manner for other people to use.

The researchers conducted this study to explore how a certain type of game, in this case a role-playing game (RPG), is integrated to make students more engaged through collaborative learning. More specifically, this study wants to address the following research questions: (1) How do students perceive the collaborative task of designing a game to create activities for classroom use? (2) How do they perceive the usefulness of the task to learn subject matters? (3) Are students interested in developing a game for classroom use?

\section{THEORETICAL FOUNDATION}

\subsection{Education}

According to John Dewey, in his book entitled "Experience and Education", education is a preparation [14]. This means that education is a form of gaining experience which is then used as stepping stones for future achievements. Moreover, he claims that one can attain future goals if he possesses experiences and understands the consequences of their decisions. In consideration of the skills possessed by students to be educated as citizenship, vocational, for leisure; then taught reading, arithmetic, geography recognize due to be useful for them in social life.

For Dewey, education is always evolving. It never ends. Education should be participatory, democratic, pluralistic, and liberal. [15].

The Indonesian model of education emphasizes the importance of having well-rounded citizens. Law No. 20 of 2003 on National Education System stipulates that the purpose of education is to create students who possess great potentials for the greater good. In addition, the Preamble of the Indonesia 1945 Constitution underlines the guidelines for the nation's intellectual life. It highlights the importance of Indonesian citizens to possess intellectual, emotional, and social intelligence. [16].

\subsection{Collaborative learning method}

The learning method is a systematic plan to achieve set learning objectives through appropriate steps. It refers to a series of related and progressive actions carried out by teachers and students [17]. There are three basic methods of teaching: teacher-centered, learner-centered and focuscentralized [17]. Each method has advantages and disadvantages. Teachers can modify or even combine one or more of the methods in order to achieve the goals of the course. The methods and strategies used by the instructor in the classroom can thoroughly teach many things so that students understand the purpose of dealing with different situations or problems in daily life [17].

There are several methods of teaching that increase student engagement. They are cooperative learning, collaborative learning, problem-based learning, inquirybased learning, peer learning and team learning.

Collaborative learning is one method of active learning registered in GAISE (The Guidelines for Assessment and Instruction in Statistics Education) of the ASA (American Statistical Association) in 2010 (recommendation number 4) which states that [18]:

"Using active learning methods in class is a valuable way to promote collaborative learning, allowing students to learn from each other... Activities offer the teacher an informal method of assessing student learning and provide feedback to the instructor on how well students are learning. It is important that teachers not underestimate the ability of activities to teach the material or overestimate the value of lectures, which is why suggestions are provided for incorporating activities, even in large lecture classes. "(p. 18)

Collaborative learning is a learning process whereby every group member contributes ideas, information, experiences, skills and ability from one to another to increase awareness amongst the members of the group [4]. Collaborative learning requires collaboration of each group member in the learning process to achieve a common goal. In a collaborative learning method, students learn from one another. They contribute their ideas equally. [19]. 
Collaborative learning is a significant shift from a process-centered teaching or teacher-centered classroom. In a collaborative classroom, lecturing may not disappear completely. Lecturing is usually used together with other methods such as class discussion, paired work, and many other methods. The most important goal of collaborative learning is to make students learn the subject matter more actively in order to improve knowledge retention. In the collaborative learning classroom, teachers are no longer the transmitter of knowledge. Instead, they become designers of intellectual experience. [20].

The following four characteristics underscore the basic assumptions of collaborative learning [20]:

1. Learning is an active, constructive process: learning is active and constructive process in which students learn new information, ideas or skills.

2. Learning depends on rich contexts: learning is fundamentally influenced by the context and the activities in which it is embedded.

3. Students are diverse: diverse students bring some new views or perspectives based on their background, experience, learning method, and their opinions.

4. Learning is inherently social: collaborative learning generates intellectual synergies to solve a problem through interactions with other group members.

\section{METHODS}

In this study, the researchers employed closed and open ended questionnaires in elicit responses. The questionnaires were distributed to 47 students consisting of freshmen, sophomores, juniors, and seniors in the Faculty of Language and Arts Soegijapranata Catholic University, Semarang, Indonesia who were taking Structure 1 course. The researchers used convenient sampling to collect data. Students who agreed to participate in this study were given a workshop to create a game using game engine called RPG Maker MV. These students did not major in computer science, because this research focused on the enthusiasm in learning new material from non-computer science students who were taught by a lecturer using collaborative learning methods that applied game development.

Since students did not major in computer science, RPG Maker MV was selected. In addition, the researchers created a template that students can readily use to create activities and exercises in the game. It is expected that by providing a template, students could put more attention into creating activities and role plays.

The questionnaire consisted of three parts. The first part was to elicit background questions such as inquiring gender and class. The second part consisted of 15 closed-ended questions with five response options. The last part consisted of three open-ended questions.

The questions were designed to find out students' perceptions of the collaborative task of designing a game in a language classroom and their interests in creating similar educational games.
This study uses descriptive statistics in the form of percentages to present the findings.

\section{SURVEY Results}

To address the research questions, the researchers asked several questions related to the task of designing the game and the exercises and their interests. When asked whether students liked creating games collaboratively, the findings indicated that $53 \%$ of the respondents liked to create games collaboratively very much, $38 \%$ liked it, $7 \%$ of the respondents reported that they felt neutral about creating games collaboratively, and the rest, $2 \%$, did not like it at all (see Figure1)

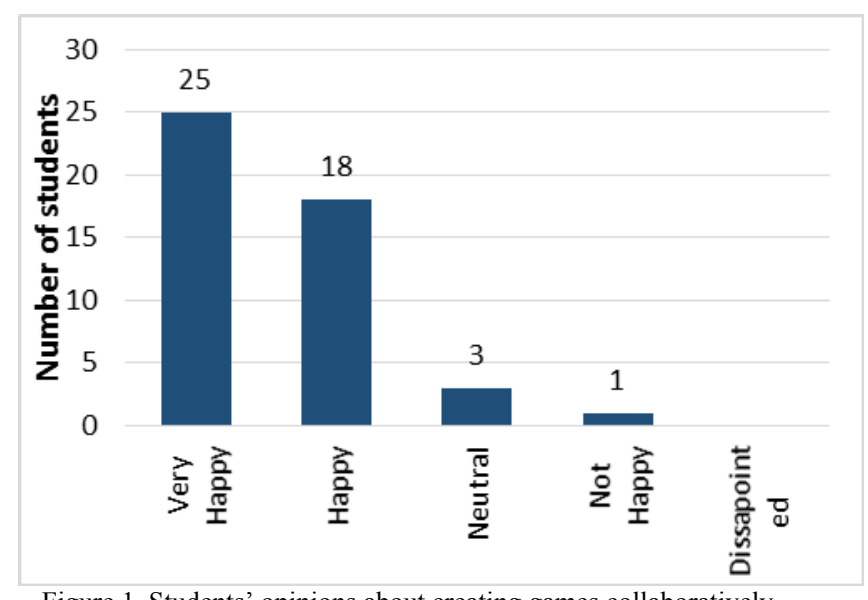

Figure 1. Students' opinions about creating games collaboratively

Figure 2 below shows students' response about the task of creating question items for the games. $26 \%$ of the respondents said they were very interested. More than half of the respondents, $55 \%$, were interested in designing questions for the game. $17 \%$ said that they felt ambivalent and $2 \%$ said they were not interested.

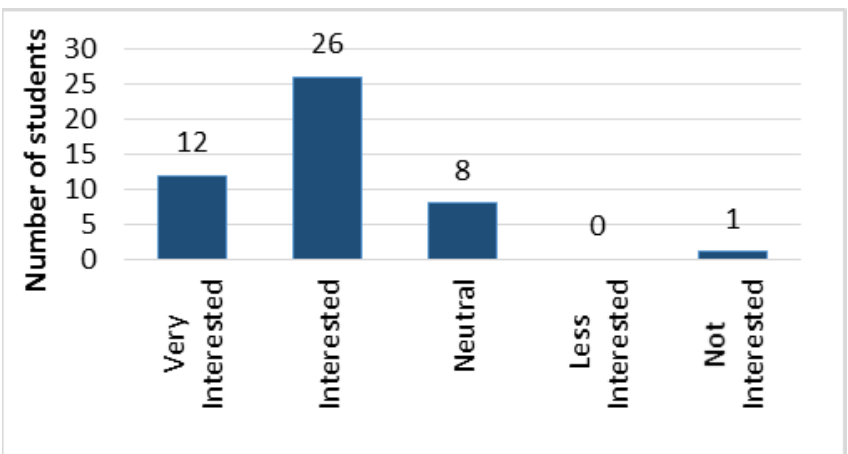

Figure 2. Students' opinions about designing questions for the game

When asked about the level of difficulty in creating the game, $17 \%$ of the respondents felt that the process was very easy. Slightly less than a half, $40 \%$, of the respondents said that it was easy. However, $43 \%$ of the respondents felt that developing the provided games was neither easy nor difficult (see Figure 3). 


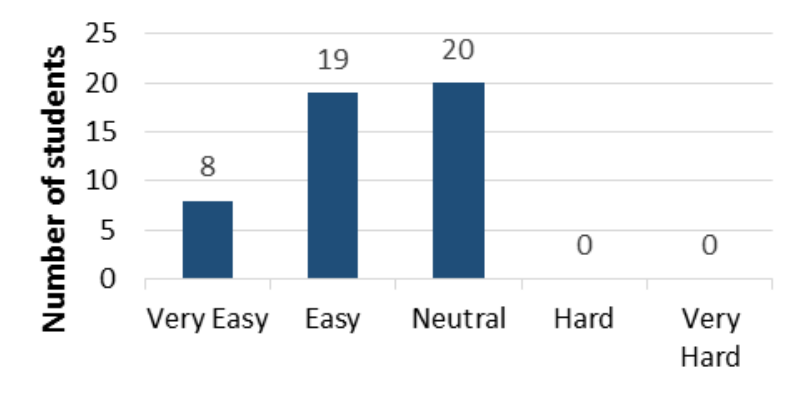

Figure 3. Students' opinions about the level of difficulty in making the game

The responses to asking opinions about the usage of the templates to assist in game development are shown in Figure 4. More than a third, 35\%, responded that the template was very helpful. Slightly more than a half of the respondents, $56 \%$, said that it was helpful. The remaining $9 \%$ said that it was neither helpful nor useless.

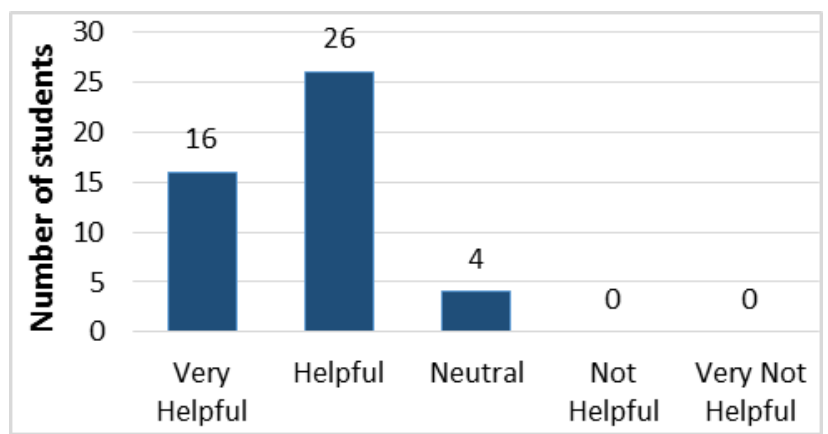

Figure 4. Students' opinions about the usefulness of the template to assist students in game development

As displayed in figure 5, most participants of this study, $89 \%$, had positive attitude towards the idea that games can be used to study a subject matter collaboratively. Only $9 \%$ disagreed and $2 \%$ of them strongly disagreed.

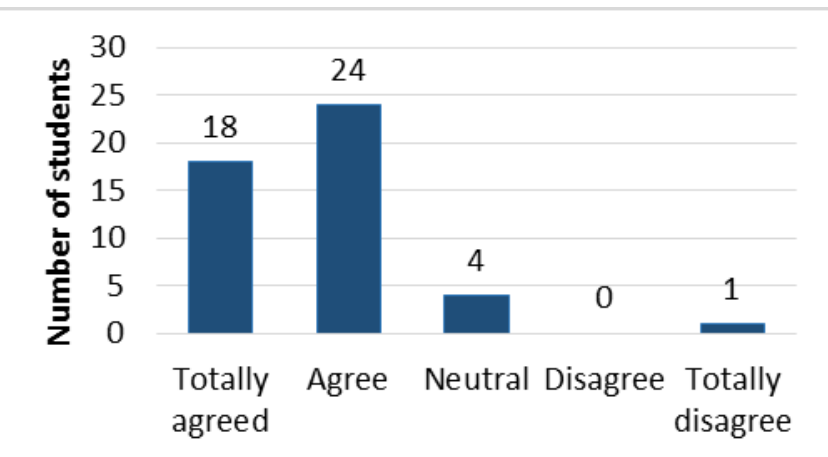

Figure 5. Students' opinions about whether games can be used to study a subject matter collaboratively

Figure 6 shows students' response for the question whether students are interested in creating a game with different topics, one fifth of the respondents reported that they were very interested and $49 \%$ said they were interested in creating more games with different topics. Less than one fifth, $17 \%$, answered neutral, and the remaining, $13 \%$, said not interested.

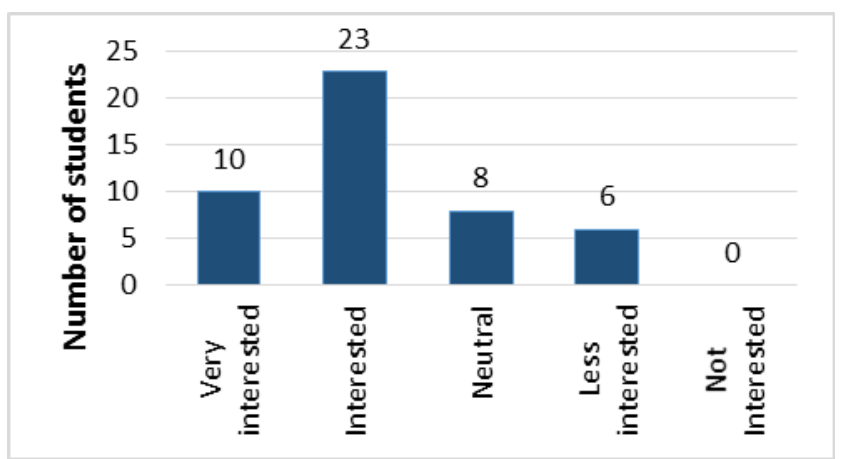

Figure 6. Students' opinions about their interest in creating a game with different topics

Statements shown in figure 7 found out whether the participants were excited for making games collaboratively. The findings show that $30 \%$ of the respondents felt very excited and $40 \%$ of respondents felt excited. $28 \%$ of them said they felt ambivalent. Only $2 \%$ responded less excited.

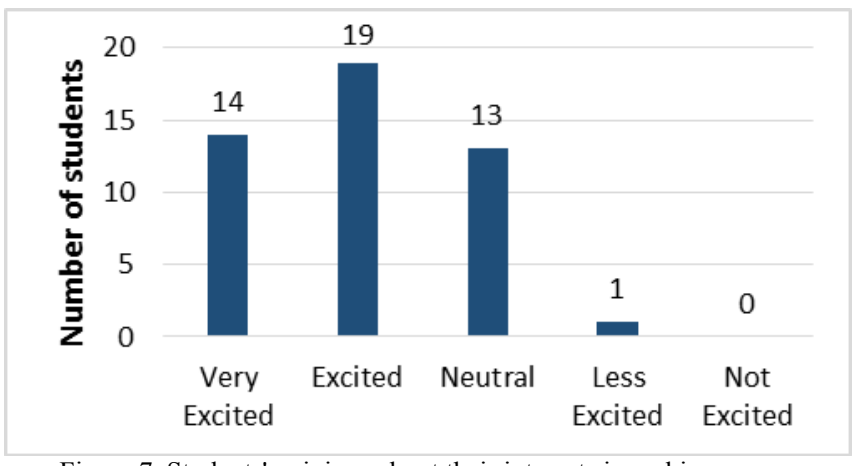

Figure 7. Students' opinions about their interests in making games collaboratively

When asked whether the need to learn a subject matter is fulfilled by developing a game, one tenth of the respondents strongly agreed. More than half of them said that the need was met. $34 \%$ said they felt neutral. Only $2 \%$ of the respondents disagreed that the game met their needs to learn a subject.

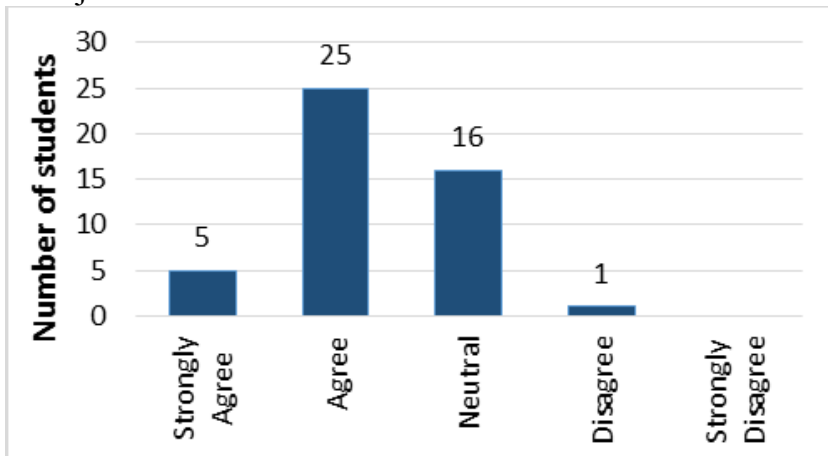

Figure 8. Students' opinions about whether a game meets their needs for learning a subject

Figure 9 shows the responses concerning whether respondents liked creating a game collaboratively. $15 \%$ of 
respondents were very interested and $49 \%$ of respondents were interested in making games. While $23 \%$ of respondents responded if they taught how to develop the game for learn together is mediocre, and $13 \%$ responded the less interested.

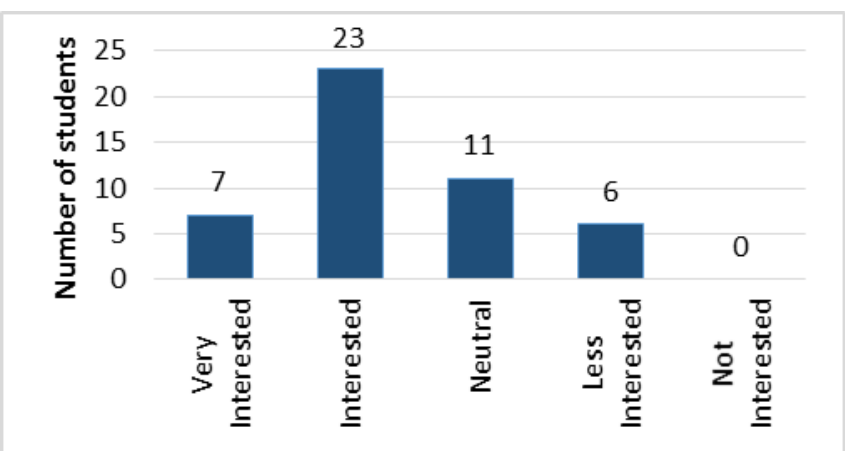

Figure 9. Students' opinions about interest in creating a games for collaborative activities

$17 \%$ of respondents were very interested and $53 \%$ of respondents were interested to share the games that they created for others. However, $26 \%$ of respondents said that they were ambivalent, and $2 \%$ were not interested.

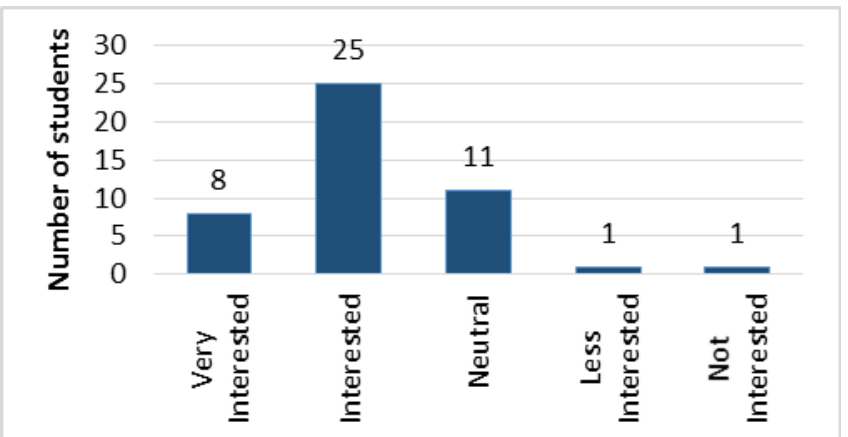

Figure 10. Students' opinions about interest to share games that they have been made to others

When asked about the usefulness of the game they created for other learners, $17 \%$ of respondents said it was very useful, $47 \%$ responded that it was useful. Thus, more than half of them showed positive attitude towards the inquiry. $32 \%$ of them said they were neutral and only $4 \%$ felt that the game was not useful for other learners.

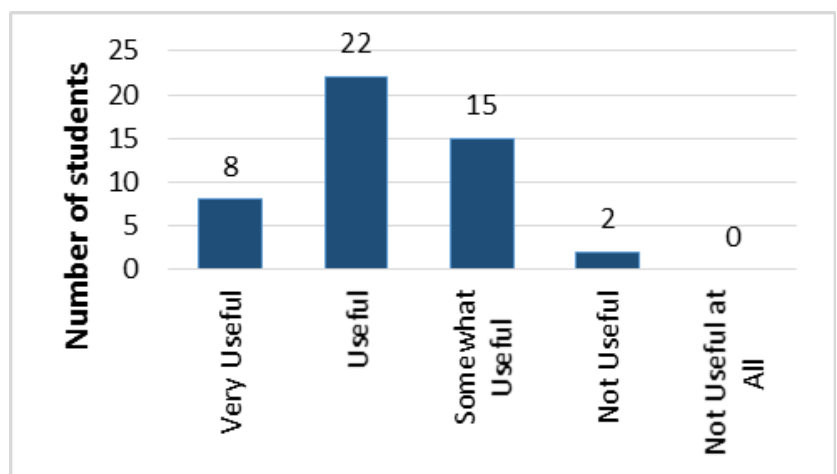

Figure 11. Students' opinions about whether the game they created could be used by others
Figure 12 shows the responses for when asked whether they agreed if the game could be played on a tablet or smartphone. More than $80 \%$ of the respondents said they agreed. . One tenth of them said they were ambivalent.

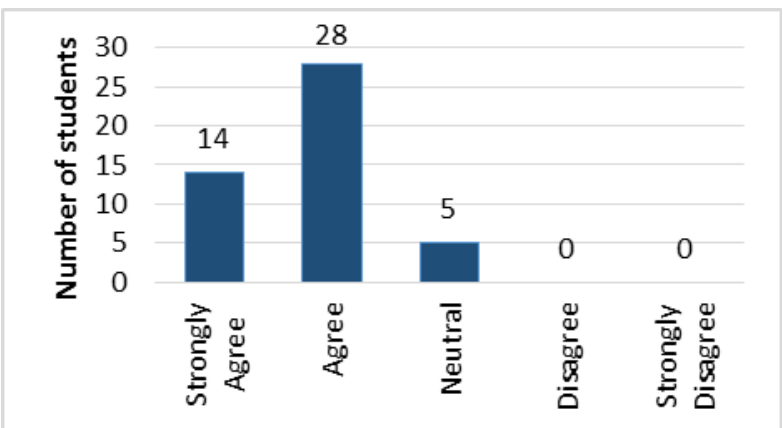

Figure 12. Students' opinions about whether a game could be played on a tablet or a smartphone

Figure 13 shows students' responses when asked whether the use of cartoon characters in the game is an attractive idea. It is described in the figure that almost all respondents expressed positive attitude toward the use of cartoon characters in a game (89\%). The remaining $11 \%$ said they were ambivalent about the question.

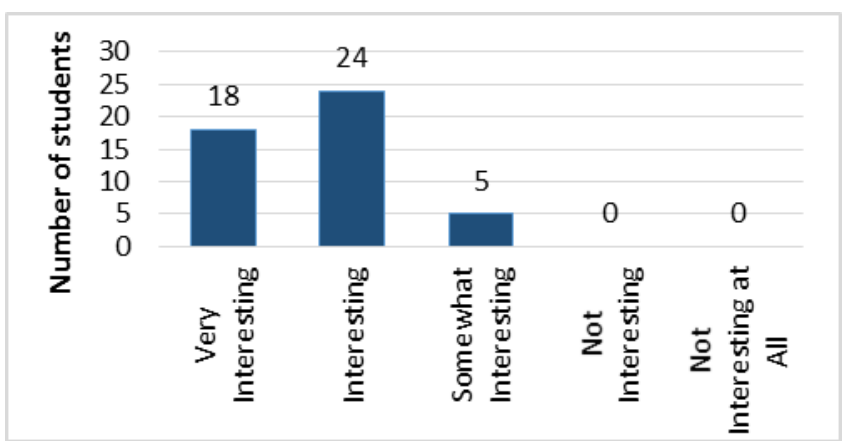

Figure 13. Students' opinions about the attractiveness of the cartoon characters in the game

Respondents were asked whether the game they created was interesting. Figure 14 shows the results of this question. The figure presents that $21 \%$ of respondents said it was very interesting, $60 \%$ responded that it was interesting. $19 \%$ of them said they were neutral about it.

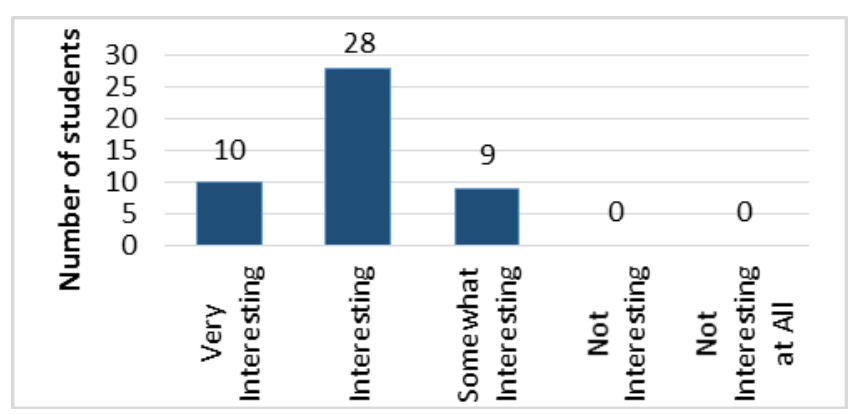

Figure 14. Students' opinions about their interests in playing Role Playing Game (RPG) 
In response to the final survey question, three fourths of the respondents said they were interested to learn how to create different kinds of games, while the rest had more negative attitudes towards the statement.

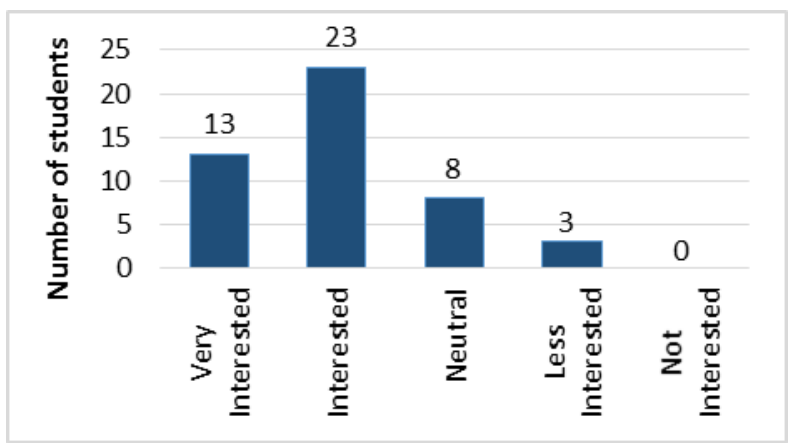

Figure 15. Students' opinions about their interests to learn how to create different kinds of games

In the third part, the open ended questions, the reseachers asked about the challenges of creating the games, the weaknesses of the game, and the kinds of games students perceive would work for collaborative learning strategies. The data indicate that students' difficulties were more related to the technical issues and their familiarity with game making. Students stated that the games would have been more attractive if the characters and the maps had been more varied. Games such as SIMS or Harvest Moon could be some of the options that are feasible to be implemented in collaborative learning classroom.

\section{CONCLUSION}

The findings of the study indicated that students who are not majoring in computer science or not familiar with game design can create a simple game for collaborative learning. Most respondents showed positive attitude towards the use of games to learn a subject matter collaboratively. The findings revealed positive attitude towards the task of creating games for classroom use. With $45 \%$ said very happy and $38 \%$ said happy, they believed the use of games will make learning become more fun. They were very excited about creating questions for the role play. It's proved with respondents said 55\% excited and $26 \%$ very excited.

Ready-to-use template was helpful since they could easily modify the games. In other words, the template provides a solid basis for students to start developing the game. Even though a few students had difficulties with the technical aspects of creating a game, they viewed the task as very interesting and useful for them. This is understandable because participants are non-computer major. Respondents said they were confident that the use of games will help them learn materials better and eventually make them better learners.

\section{ACKNOWLEDGMENT}

This paper is a part of a research project funded by the Indonesian Directorate General of Higher Education in the year 2016 under the scheme of International Collaboration and Publication grant.

\section{REFERENCES}

[1] E. Lehtinen, K. Hakkarainen, L. Lipponen, M. Rahikainen, and H. Muukkonen, "Computer supported collaborative learning: A review," JHGI Giesbers Reports Educ., pp. 1-58, 1999.

[2] N. Suryani, "Implementasi Model Pembelajaran Kolaboratif untuk Meningkatkan Ketrampilan Sosial Siswa," J. Soc. Sci., 2008.

[3] Government of Republic of Indonesia, Act of the Republic of Indonesia, number 20, year 2003, on national education system, no. 20. Indonesian: lanipolis.iiep.unesco.org, 2003, pp. 1-58.

[4] Sudarman, "Penerapan Metode Collaborative Learning untuk Meningkatkan Pemahaman Materi Mata Kuliah Metodologi Penelitian," J. Soc. Sci., vol. 3, no. 1, pp. 94-100, 2003.

[5] G. Stahl, T. Koschmann, and D. Suthers, "Computer-supported collaborative learning: An historical perspective," Cambridge Handb. Learn. Sci., no. 2006, pp. 409-426, 2006.

[6] M. Papastergiou, "Online Computer Games as Collaborative Learning Environments: Prospects and Challenges for Tertiary Education," J. Educ. Technol. Syst., vol. 37, no. 1, pp. 19-38, 2008.

[7] D. Schaffhauser, "Will Gaming Save Education , or Just Waste Time?," THE Journal, pp. 1-5, 2013.

[8] Erwin, "2016, Indonesia Empat Besar Pengguna Smartphone," koran.tempo.co, $2015 . \quad$ [Online]. Available: http://koran.tempo.co/konten/2015/01/24/363157/2016Indonesia-Empat-Besar-Pengguna-Smartphone. [Accessed: 01Jan-2016].

[9] R. Sanjaya, A. E. M. Soekesi, and A. P. S. Sitohang, "Technology entrepreneurship model development for teachers," Int.J.Technoentrepreneurship, vol. 3, no. 1, pp. 60-66, 2015.

[10] X. H. X. He and W. H. W. Hu, "An Innovative Web-Based Collaborative Learning Model and Application Structure," in 2008 International Conference on Computer Science and Software Engineering, 2008, vol. 5, pp. 56-59.

[11] D. B. Clark, E. E. Tanner-smith, and S. Killingsworth, "Digital Games for Learning: A Systematic Review and Meta-Analysis Preliminary Meta-Analysis Results," 2015.

[12] P. Backlund and M. Hendrix, "Educational games-are they worth the effort? A literature survey of the effectiveness of serious games," Games Virtual Worlds Serious Appl. 2013 5th Int. Conf., no. December, 2013.

[13] K.-Y. Liu, C.-T. Yang, and K.-H. Chang, "Development of a multiplayer online role-playing game-based learning system for multiple curriculums," in Digital Game and Intelligent Toy Enhanced Learning (DIGITEL), 2012 IEEE Fourth International Conference on, 2012, pp. 62-66.

[14] Kappa Delta Pi, John Dewey Experience \& Education, Touchstone. New York: Simon \& Schuster Inc., 1997.

[15] T. Rostitawati, "Konsep pendidikan john dewey," J. Manaj. Pendidik. Islam, vol. 02, pp. 133-139, 2014.

[16] A. T. Putra, "Tujuan Pendidikan," Academia.edu, 2010. [Online]. Available:

https://www.academia.edu/4563266/MAKALAH TUJUAN PE NDIDIKAN. [Accessed: 04-Feb-2016].

[17] J. R. Abanador, G. C. D. Buesa, G. M. L, and J. Mañibo, "Teaching Methods and Learning Preferences in the Engineering Department of an Asian University," Int. J. Acad. Res. Progress. Educ. Dev., vol. 3, no. 1, pp. 1-15, 2014.

[18] S. A. Kalaian and R. M. Kasim, "A Meta-analytic Review of Studies of the Effectiveness of Small- Group Learning Methods on Statistics Achievement," J. Stat. Educ., vol. 22, no. 1, pp. 120, 2014.

[19] M. Dooly, "Constructing Knowledge Together," Telecollaborative Lang. Learn. A Guideb. to Moderating Intercult. Collab. Online, pp. 21-45, 2008.

[20] B. L. Smith and J. MacGregor, "What is Collaborative Learning?," Collab. Learn. A Sourceb. High. Educ., pp. 1-11, 1992. 


\section{Doc vs Internet + Library}

$92.4 \%$ Originality
$7.6 \%$ similarity
159 sources

\section{Web sources: 114 sources found}

1. https://cpb-us-e1.wpmucdn.com/sites.pc.gsu.edu/dist/e/102/files/2015/01/GAISECollege_Recomm...

2. http://www.vnseameo.org/InternationalConference2017/materials/17_RidwanSanjaya_CeciliaTitiekM.

3. http://www.vnseameo.org/InternationalConference2017/conference-program

4. https://onlinelibrary.wiley.com/doi/full/10.1111/j.1467-8535.2006.00593.x

5. https://onlinelibrary.wiley.com/doi/abs/10.1111/1467-8535.00325

6. http://journal.unika.ac.id/index.php/celt/article/view/1173/pdf

7. http://journal.unika.ac.id/index.php/celt/article/view/566

8. https://link.springer.com/article/10.1007/s12528-016-9107-z

9. http://journal.unika.ac.id/index.php/celt/article/download/566/pdf_4

10. https://educationaltechnologyjournal.springeropen.com/articles/10.1186/s41239-017-0062-1

11. http://dice.newcastle.edu.au/DRS_5_2017.pdf

12. https://pacotartera.blogspot.com/2012/03/2012-1-ucjc-tceie-las-tecnologias-de-la.html

13. https://blogs.commons.georgetown.edu/cctp-820-fall2015/category/final-project

14. http://www.wseas.org/multimedia/journals/information/2013/5709-113.pdf

15. https://www.smartdraw.com/lesson-plan

16. https://core.ac.uk/download/pdf/11722762.pdf

17. https://www.ijsce.org/download/volume-1-issue-6

18. https://link.springer.com/article/10.1186/1475-2891-11-48

19. http://www.ukm.my/geografia/images/upload/7x.geografia-si-feb16-norasiah-edam\%20(1).pdf

20. https://psychcentral.com/blog/threats-hidden-in-the-moral-of-the-story

21. http://ceur-ws.org/Vol-1009/0408.pdf

22. http://www.ejmanager.com/mnstemps/67/67-1441007236.pdf

23. http://onlinepubs.trb.org/onlinepubs/conferences/2011/RSS/2/Dissanayake,Su.pdf

24. https://nutritionj.biomedcentral.com/track/pdf/10.1186/1475-2891-11-48? site=nutritionj.biomedcen...

25. https://onlinelibrary.wiley.com/doi/10.1111/j.1469-7610.1976.tb00381.x

26. https://www.ncbi.nlm.nih.gov/pmc/articles/PMC3418187

27. https://nutritionj.biomedcentral.com/articles/10.1186/1475-2891-11-48

28. http://ijbssnet.com/journals/Vol_6_No_8_1_August_2015/8.pdf

29. https://www.onlinelibrary.wiley.com/doi/full/10.1111/j.1540-4609.2007.00125.x

30. https://www.cmawebline.org/images/stories/JAMAR_2012_Winter/JAMARv10.1-Adoption-Innovat...

31. https://mynvqresources.yolasite.com/resources/Basic\%20Guide\%20to\%20Leadership\%20and\%2...

32. http://icemal.conference.upi.edu/pages/abstracts1.php

33. https://www.slideshare.net/yogeshtanpure/reward-management-52319546 
35. http://onlinelibrary.wiley.com/doi/10.1111/nyas.12498/full

36. https://www.nsf.gov/bfa/dias/policy/hsfaqs.jsp

37. http://www.routledge.com/textbooks/eresources/9780415566421/yasuyo.pdf

$0.2 \%$

38. http://www.sru.edu.kh/download.php?file=leadership-and-supervision.pdf

$0.2 \%$

39. https://tspace.library.utoronto.ca/bitstream/1807/70740/1/Yang_Yehbeen_201511_MA_thesis.pdf

$0.2 \%$

40. https://dbhids.org/wp-content/uploads/2017/09/OCIO_DBHIDS-Data-Governance-Framework-Imp...

$0.2 \%$

41. http://ijarcsms.com/docs/paper/volume2/issue6/V216-0003.pdf

$0.2 \%$

42. http://accentsjournals.org/PaperDirectory/Journal/IJACR/2014/6/24.pdf

$0.2 \%$

43. https://www.kingcounty.gov/business/oirm/governance/strategicadvisorycounci//meetings/ /medi...

44. https://viceprovost.tufts.edu/sberirb/files/HIPAA_PHI_Use.doc

$0.2 \%$

45. https://www.grossarchive.com/project/1245/THE-ATTITUDE-OF-COLLEGE-OF-EDUCATION-STU.

$0.2 \%$

46. http://repository.wcsu.edu/cgi/viewcontent.cgi?article=1057\&context=educationdis

$0.2 \%$

47. http://scholarcommons.usf.edu/cgi/viewcontent.cgi?article=1305\&context=jpt

$0.2 \%$

48. https://www.midwestern.edu/Documents/protected/student_employee/CHS\%20PSYCH/Clinical\%...

$0.2 \%$

49. http://ro.ecu.edu.au/cgi/viewcontent.cgi?article=1494\&context=theses

$0.2 \%$

50. http://kisi.deu.edu.tr/oguz.serin/ijtase_vol2_1_7.pdf

51. https://www.unicef.org/protection/files/2009_Global_Thematic_Report_FINAL.pdf

$0.2 \%$

52. https://mindprintlearning.com/free-resources

$0.2 \%$

53. http://www.jms.nonolympictimes.org/Articles/marticle.pdf

$0.2 \%$

$0.2 \%$

54. http://afterabortion.org/1999/abortion-risks-a-list-of-major-physical-complications-related-to-abortion

$0.2 \%$

55. https://bmcpsychology.biomedcentral.com/articles/10.1186/s40359-015-0090-3

$0.2 \%$

56. https://www.nap.edu/read/23534/chapter/2

$0.2 \%$

57. https://www.webmd.com/add-adhd/childhood-adhd/features/adhd-and-video-games-is-there-a-link

$0.2 \%$

58. https://ttu-ir.tdl.org/ttu-ir/bitstream/handle/2346/9179/31295001328136.pdf;sequence=1

$0.2 \%$

59. https://quizlet.com/17925556/chap-14-emotions-as-motives-flash-cards

$0.2 \%$

60. http://www.businessdictionary.com/definition/system.html

61. https://nutritionj.biomedcentral.com/articles/10.1186/1475-2891-7-32

$0.2 \%$

$0.2 \%$

62. https://digiparenthood.wordpress.com/2013/08/23/10-benefits-of-exposing-young-children-to-mode.

$0.2 \%$

63. http://www.anpad.org.br/admin/pdf/2012_MKT922.pdf

$0.2 \%$

64. https://sro.sussex.ac.uk/view/year/2010.type.html

65. http://wellness.ucr.edu/Smoking\%20and\%20Tobacco\%20Cessation\%20Resource\%20List\%20.pdf

66. http://irep.ntu.ac.uk/view/collection/Research_and_Scholarly_Collection/2014.html

67. https://arxiv.org/pdf/1411.1897

68. http://file.scirp.org/pdf/JSS_2015102310050828.pdf

69. http://www.macrothink.org/journal/index.php/ijhrs/article/viewFile/5873/4762

$0.2 \%$

70. http://file.scirp.org/pdf/FNS_2013060514562373.pdf

71. https://arxiv.org/pdf/1606.00747

72. https://link.springer.com/content/pdf/10.1186/1472-6963-3-21.pdf

73. http://oa.upm.es/30855/1/ENRIQUE_BARRA_ARIAS.pdf

74. https://www.ncbi.nlm.nih.gov/pmc/articles/PMC3368483

75. https://www.vu.edu.au/sites/default/files/research/pdfs/ethics-children-handbook.pdf

76. http://www.euro.who.int/_data/assets/pdf_file/0003/108966/E91193.pdf

77. https://journals.sagepub.com/doi/10.1177/2056305117746356

78. https://open.library.ubc.ca/handle/2429/38089

79. https://cfo.university/library/article 
81. https://www.kingsfund.org.uk/sites/files/kf/field/field_document/health-promotion-ill-health-prevent...

82. https://www.bangor.ac.uk/arts-humanities-and-business/news/alpha

83. http://waragainsteatingdisorder.com/2019/01/29/dieting-practices-body-image-perception-among-le .

84. https://www.shrm.org/hr-today/news/hr-magazine/Pages/0812boudreau.aspx

85. https://www.iiste.org/Journals/index.php/EJBM/article/viewFile/14794/15276

$0.2 \%$

86. https://www.sheilapantry.com/oshworld/links/c3.html

$0.2 \%$

87. https://learnmgt.weebly.com/introduction1.html

$0.2 \%$

88. http://www.cs.bilkent.edu.tr/ gudukbay/citations/node3.html

$0.2 \%$

89. https://arxiv.org/pdf/1707.07452

90. https://scholarworks.uvm.edu/cgi/viewcontent.cgi?article $=1375 \&$ context=graddis

$0.2 \%$

91. https://bmcpalliatcare.biomedcentral.com/articles/10.1186/s12904-017-0244-6

92. http://www.all-Ilc.com/publicdownloads/ALLConsulting-WaterTreatmentOptionsReport.pdf

$0.2 \%$

93. http://www.scielo.br/scielo.php?script=sci_arttext\&pid=S0104-11692006000600003

$0.2 \%$

94. http://www.asiatefl.org/main/download_pdf.php?i=73\&c=1419298337

$0.2 \%$

95. https://www.odi.org/resources/docs/6248.pdf

$0.2 \%$

96. http://journals.sagepub.com/doi/abs/10.3102/0013189X09336671?journalCode=edra

$0.2 \%$

97. https://journals.sagepub.com/doi/full/10.1177/1550147718757665

$0.2 \%$

98. http://apjcn.nhri.org.tw/server/APJCN/20/1/21.pdf

99. http://www.headconf.org/wp-content/uploads/pdfs/2636.pdf

$0.2 \%$

100. https://www.science.gov/topicpages/c/childhood+education+teachers.html

101. http://www.delhibusinessreview.org/V14_N2/v14n2a_pg1-18.pdf

102. https://www3.nd.edu/ nchawla/papers/bigdata13.pdf

103. http://scielo.isciii.es/pdf/pharmacin/v12n2/original06.pdf

104. http://digitalcommons.liberty.edu/cgi/viewcontent.cgi?article=1504\&context=doctoral

105. https://www.kingsfund.org.uk/sites/default/files/field/field_document/health-promotion-ill-health-p...

106. https://www.stat.auckland.ac.nz/ iase/serj/SERJ11(2)_Bond.pdf

$0.2 \%$

107. http://wseas.us/e-library/transactions/communications/2010/89-351.pdf

108. https://dc.etsu.edu/cgi/viewcontent.cgi?article $=4717 \&$ context=etd

109. https://deepblue.lib.umich.edu/bitstream/handle/2027.42/97992/berhenke_1.pdf?sequence=1

110. http://ir.uiowa.edu/cgi/viewcontent.cgi?article $=5061$ \&context=etd

111. https://digitalcommons.salemstate.edu/cgi/viewcontent.cgi?article=1111\&context=honors_theses

\section{Library sources: 45 sources found}

student as prod.pdf

Rut_Thesis akhir.docx

FIX-FINAL PROJECT_MICHAEL_FBS_kirim.pdf

Fildzah_Checked.docx 
Ivena Felita_Skripsi.docx

jurnal_design dataflow diagram (1).pdf

GRACE NATHANIA THESIS - MASUK.docX

wana warior -- sisforma.pdf

jati.docx

26 JULi 2018 - Khoe Yohana Harsono - 14.J1.0051.docx

emdSTELLA- A FIGURATIVE LANGUAGE (1).docx

FINALPROJECT_NATASHAWIJAYA_14.J2.0005_ENGPRE.docx

Thesis Jenifer Andriyani_14.J1.0009_chapter 1-5_revised_3 Ma.doc

ver. emd 16-mar-18 FINAL.doc

$0.49 \%$

AMADEA THESIS.docX

THESIS_TIARA PERMATA SARI_12.80.0025_SASTRA INGGRIS.docx

AMADEA THESIS.docx

Y.E.Budiyana - Article - The Impacts of the TOEFL CD Rom Pra.docx

26 JULi 2018 - Khoe Yohana Harsono - 14.J1.0051.docx

Bab 1-5 thesis alan selesai.docx- Alan july 25 KIRIM.docx

Rona Azizah, Susan Edelweis, Angelika Riyandari-Representing.docx

SKRIPSI - KAREL VICTORIO.docx

Final Project_Sharen Theodora Budianto_14.J2.0003_Englishpre.docx

14.J1.0013 SESILIA NOVITA SARI-THESIS.docx

14.J2.0061 - DWI PUTRI R.docx

11.80.0017 Eunike Isrumanti (1).docx

Albertus Dwi Yoga revisi Integration of Internet Technology .doc

Making Education Game to Choose Healthy Snacks for Children .pdf

draft english Increase student awareness of people's cultura.docx

SKRIPSI-CLAUDIA GABBY.docx

1173-2700-1-SM.pdf

14J2.0041 Elizabeth Yunita.docx

14.j1.0037 Jane ellen giovani.docx

14J20032 Jeannete Angelina.doc

the implicatiom.pdf

Warak Dance - research proposal.doc 


\section{(U) UNICHECK}
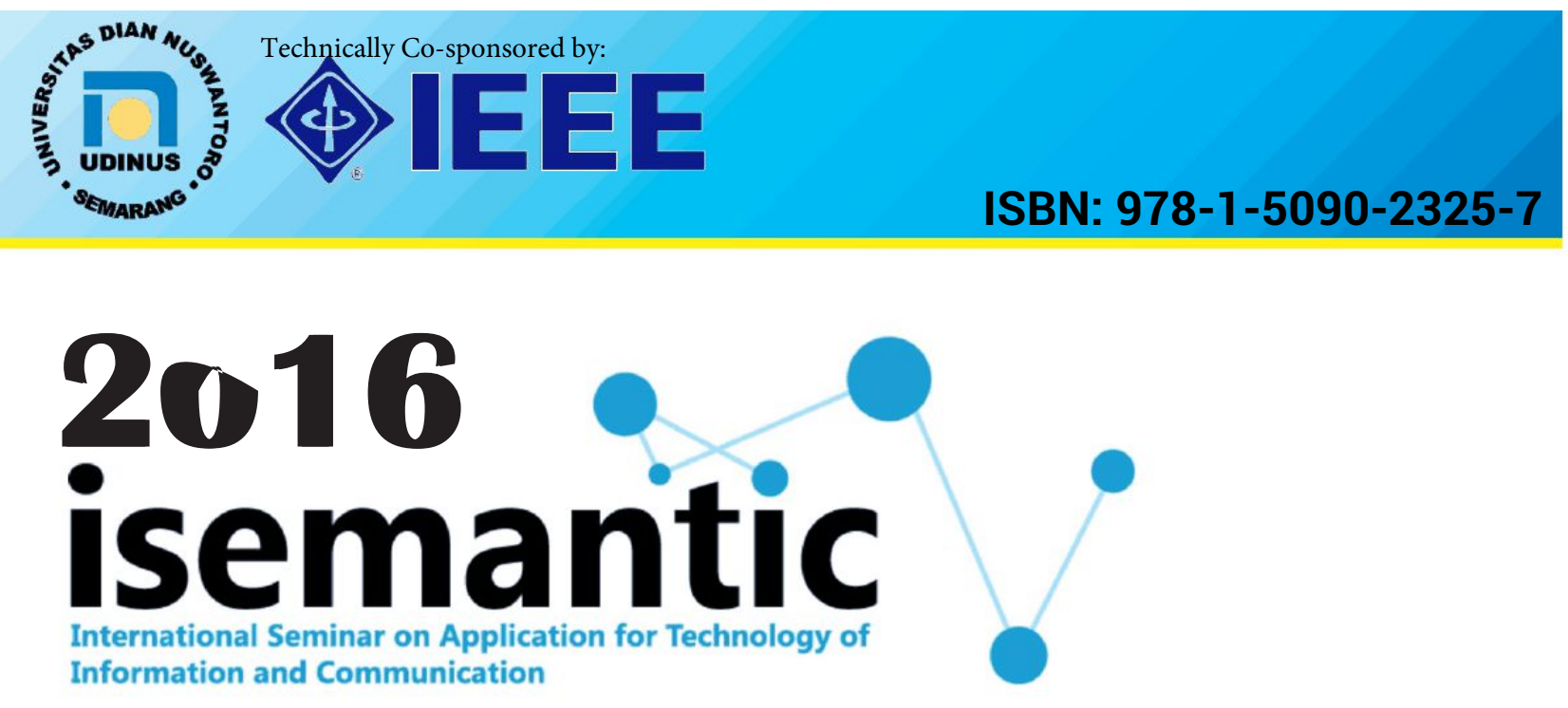

International Seminar on Application for Technology of

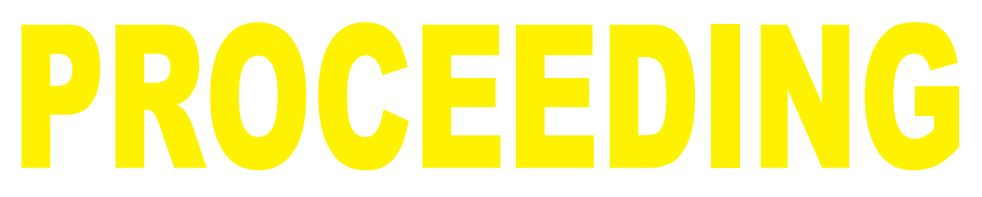

\section{Seience and Technology for a Better fulure Ist International Seminar on Application for Technology of Information and Communication}

Arigust 5in - 6th, 2016 Universilas Diam Nusmantoro Semmant. Imdonesia 


\section{Developing Educational Game for Collaborative Learning}

\author{
Aprilia Ratna Christanti \\ Game Technology Program, \\ Information Systems Department, \\ Faculty of Computer Science, \\ Soegijapranata Catholic University \\ Semarang, Indonesia \\ 13070029@student.unika.ac.id
}

\author{
Ridwan Sanjaya \\ Information Systems Department, \\ Faculty of Computer Science, \\ Soegijapranata Catholic University \\ Semarang, Indonesia \\ ridwan@unika.ac.id
}

\author{
Cecilia Titiek Murniati \\ English Department, \\ Faculty of Language and Arts, \\ Soegijapranata Catholic University \\ Semarang, Indonesia \\ c_murniati@unika.ac.id
}

Abstract-Nowadays, conventional methods of learning arkearning strategies should be well designed in order to create no longer enthused by students, because a one-way teachingll rounded students.

method makes students easily bored. Collaborative learning In Indonesia, the teaching and learning aproach, methods are used to make students more interested in learniespecially in K-12 settings, is mostly based on grades. and encourage students to actively contribute to the classrogmeachers and parents pay more attention to grades instead of session. One of the benefits of collaborative learning as the actual learning process. Students learn course contents learning method is that it allows each student in a group to rote memorization[4]. 2013 educational curriculum was
actively contribute and share their ideas. An example ofy collaborative learning implementation in the classroom isdesigned as an attempt to change the educational paradigm, computer-supported collaborative learning (CSCL). CSCL is a but it was not popular among K-12 teachers and policy type of collaborative learning technique in which students camakers. In higher education institutions, however, the learn a subject matter with their peers using computers. Suabaching and learning paradigm is slightly different from strategies could be implemented in the form of digital games taat in K-12 education because teachers have more freedom make the collaborative learning methods more attractive and determine the most appropriate teaching strategies that interactive. This paper attempts to investigate students'can sharpen students' critical thinking skills.

perception toward the collaborative task of designing a game sharpen students' critical thinking skills. students showed positive attitude towards the task becauses $\mathrm{s}^{9}$ that students become more creative, innovative, and allowed them to understand the subject matter better. engaged. Some of the methods that teachers often use are collaborative and cooperative learning. Cooperative learning

Keywords-collaborative learning; digital game; gamerefers to a teaching method in which students divide tasks design; educational game; mobile application among group members, whereas collaborative learning is a

\section{I NTRODUCTION}

Science plays a vital role in developing social and economic status worldwide [1]. The advancement of science and technology brings the global society to prosperity. The strategy to master advanced science and technology is to educate people to become excellent human resources that can compete internationally[2].

Indonesian government enacted Law No. 20 of 2003 on National Education System, therein described the meaning of education in paragraph 1 of Article 1, which states "Education means a conscious and well-planned effort in creating a learning environment and learning process so that students will be able to develop their full potential for acquiring spiritual and religious strengths, develop selfcontrol, personality, intelligence, morals, noble character and skills that one needs for him/herself, for the community, for the nation, and for the Sate." [3]. The law clearly encourages students to actively develop their potential in order to better understand what they learn. The teaching and learning method in which each stident contributes their skills and strengths to accomplish a task together. These methods can be combined to obtain the best learning experience. Teachers use various tools including digital media, which was known as computer-supported collaborative learning (CSCL). CSCL is a type of collaborative learning technique in which students can learn a subject matter with their peers using computers [5].

With CSCL, teachers can also create digital games to increase student engagement and attract students' interest. Digital games can be used not only for entertainment, but also as an interactive, unique, and effective learning media [6]. Salen claims that the use of games in education is acceptable as long as the games are "rich with data". A good educational game is one that has a lot of instructions for players such as how to play the game, what players should do to complete the game, how they get points or bonuses, and so on [7]. 
The growth of computer technology and its increasing number of users, particularly for mobile devices or smartphones worldwide, has been predicted to exceed two billion in 2016. The results of the survey firm eMarketer showed that smartphone users increased by $12.6 \%$ from 2015 , from 1.91 billion to 2,16 billion [8]. This has created greater opportunities for creative industries based on games. Anyone who has an interest in computer games, including teachers and lecturers, has the opportunity to be involved in the development of educational games. Teachers have the knowledge and experience, based on thei respective fields of study, which they can use to develop the content of educational games [9]

Recent literature also indicates that games are used mostly by users of gadgets or mobile devices; thereby educational games have a potential to be incorporated as a media of collaborative learning methods [10]. Games can be used and integrated in the teaching and learning process. However, teachers need to select the most appropriate games if depending on students' technological confort level, students' interest and abilities, subject matters, and goals of the course. [11]

Meta-analysis studies on the effectiveness of serious games for learning reveal mixed results. However, serious games do have positive effects on motivation and class engagement [12]. Piiraine-Marsh and Taino (2009) examined how their research participants engaged and interacted when playing the game. They found that games provided ample interactional opportunities when they played the games. Game based learning approach, in addition, can promote students problem solving skills and increase learning motivation [13].

Previous studies on serious games focused more on the ready to use games. The participants were tested as the users of games. In this study, however, the researchers would like to use games as a tool to work collaboratively. In other words, the participants in this study were asked to design a game and create activities and exercises in a collaborative manner for other people to use.

The researchers conducted this study to explore how a certain type of game, in this case a role-playing game (RPG), is integrated to make students more engaged through collaborative learning. More specifically, this study wants to address the following research questions: (1) How di students perceive the collaborative task of designing a game to create activities for classroom use? (2) How do they perceive the usefulness of the task to learn subject matters?

(3) Are students interested in developing a game for classroom use?

\section{THEORETICAL FOUNDATION}

\subsection{Education}

According to John Dewey, in his book entitled "Experience and Education", education is a preparation [14]. This means that education is a form of gaining experience which is then used as stepping stones for future achievements. Moreover, he claims that one can attain future goals if he possesses experiences and understands the consequences of their decisions. In consideration of the skills possessed by students to be educated as citizenship, vocational, for leisure; then taught reading, arithmetic, geography recognize due to be useful for them in social life.

For Dewey, education is always evolving. It never ends. Education should be participatory, democratic, pluralistic, and liberal. [15].

The Indonesian model of education emphasizes the importance of having well-rounded citizens. Law No. 20 of 2003 on National Education System stipulates that the purpose of education is to create students who possess great potentials for the greater good. In addition, the Preamble of the Indonesia 1945 Constitution underlines the guidelines for the nation's intellectual life. It highlights the importance of Indonesian citizens to possess intellectual, emotional, and social intelligence. [16].

\subsection{Collaborative learning method}

The learning method is a systematic plan to achieve set learning objectives through appropriate steps. It refers to a series of related and progressive actions carried out by teachers and students [17]. There are three basic methods of teaching: teacher-centered, learner-centered and focuscentralized [17]. Each method has adantages and disadvantages. Teachers can modify or even combine one or more of the methods in order to achieve the goals of the course. The methods and strategies used by the instructor in the classroom can thoroughly teach many things so that students understand the purpose of dealing with different situations or problems in daily life [17].

There are several methods of teaching that increase student engagement. They are cooperative learning, collaborative learning, problem-based learning, inquirybased learning, peer learning and team learning.

Collaborative learning is one method of active learning registered in GAISE (The Guidelines for Assessment and Instruction in Statistics Education) of the ASA (American Statistical Association) in 2010 (recommendation number 4) which states that [18]:

"Using active learning methods in class is a valuab way to promote collaborative learning, allowing student learn from each other... Activities offer the teacher informal method of assessing student learning and pro feedback to the instructor on how well students learning. It is important that teachers not underestimat ability of activities to teach the material or overestimat value of lectures, which is whv suquestions are provide incorporating activities, even in large lecture classes. 18)

Collaborative learning is a learning process whereby every group member contributes ideas, information, experiences, skills and ability from one to another to increase awareness amongst the members of the group [4] Collaborative learning requires collaboration of each group member in the learning process to achieve a common goal. In a collaborative learning method, students learn from one another. They contribute their ideas equally. [19] 
Collaborative learning is a significant shift from a process-centered teaching or teacher-centered classroom. In a collaborative classroom, lecturing may not disappear completely. Lecturing is usually used together with other methods such as class discussion, paired work, and many other methods. The most important goal of collaborative learning is to make students learn the subject matter more actively in order to improve knowledge retention. In the collaborative learning classroom, teachers are no longer the transmitter of knowledge. Instead, they become designers of intellectual experience. [20].

The following four characteristics underscore the basic assumptions of collaborative learning [20]:

1. Learning is an active, constructive process: learning active and constructive process in which students learn new information, ideas or skills.

2. Learning depends on rich contexts: learning is fundamentally influenced by the context and the activities in which it is embedded.

3. Students are diverse: diverse students bring some new views or perspectives based on their background, experience, learning method, and their opinions.

4. Learning is inherently social: collaborative learning generates intellectual synergies to solve a probem through interactions with other group members.

\section{METHODS}

In this study, the researchers employed closed and open ended questionnaires in elicit responses. The questionnaires were distributed to 47 students consisting of freshmen, sophomores, juniors, and seniors in the Faculty of Language and Arts Soegijapranata Catholic University Semarang Indonesia who we taking Structure 1 course. The researchers used convenient sampling to collect data. Students who agreed to participate in this study were given a workshop to create a game using game engine called RPG Maker MV. These students did not major in computer science, because this research focused on the enthusiasm in learning new material from non-computer science students who were taught by a lecturer using collaborative learning methods that applied game development.

Since students did not major in computer science, RPG Maker MV was selected. In addition, the researchers created a template that students can readily use to create activities and exercises in the game. It is expected that by providing a template, students could put more attention into creating activities and role plays.

The questionnaire consisted of three parts. The first part was to elicit background questions such as inquiring gender and class. The second part consisted of 15 closed-ended questions with five response options. The last part consisted of three open-ended questions.

The questions were designed to find out students' perceptions of the collaborative task of designing a game in a language classroom and their interests in creating similar educational games.
This study uses descriptive statistics in the form of percentages to present the findings.

\section{SuRVEY RESUlts}

To address the research questions, the researchers asked several questions related to the task of designing the game and the exercises and their interests. When asked whether students liked creating games collaboratively, the findings indicated that $53 \%$ of the respondents liked to create games collaboratively very much, $38 \%$ liked it, $7 \%$ of the respondents reported that they felt neutral about creating games collaboratively, and the rest, $2 \%$, did not like it at all (see Figure1)

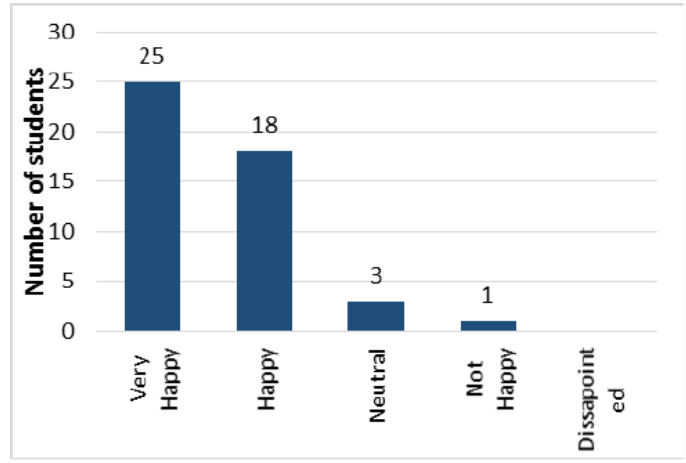

Figure 1. Students' opinions about creating games collaboratively

Figure 2 below shows students' response about the task of creating question items for the games. $26 \%$ of the respondents said they were very interested. More than half of the respondents, $55 \%$, were interested in designing questions for the game. $17 \%$ said that they felt ambivalent and $2 \%$ said they were not interested.

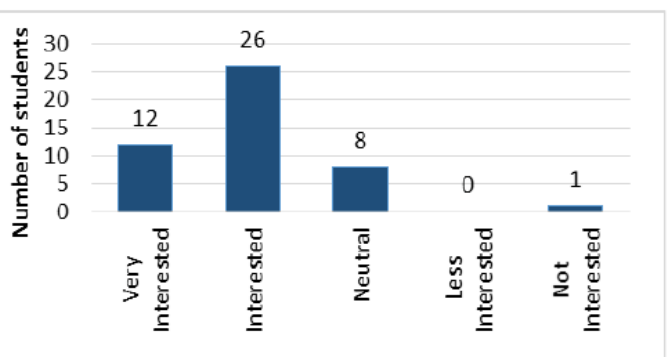

Figure 2. Students' opinions about designing questions for the game

When asked about the level of difficulty in creating the game, $17 \%$ of the respondents felt that the process was very easy. Slightly less than a half, $40 \%$, of the respondents said that it was easy. However, $43 \%$ of the respondents felt that developing the provided games was neither easy nor difficult (see Figure 3). 


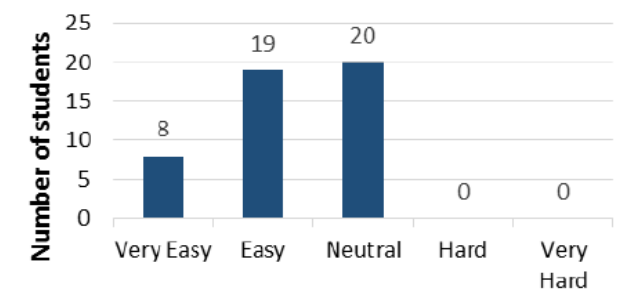

Figure 3. Students' opinions about the level of difficulty in making the game

The responses to asking opinions about the usage of the templates to assist in game development are shown in Figure 4. More than a third, 35\%, responded that the template was very helpful. Slightly more than a half of the respondents, $56 \%$, said that it was helpful. The remaining $9 \%$ said that it was neither helpful nor useless.

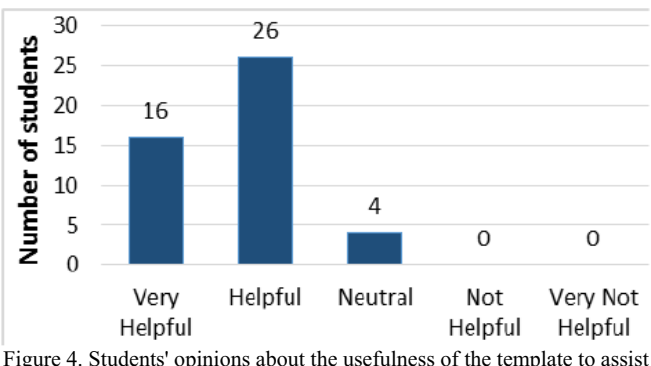

Figure 4. Students' opinions about the usefulness of the template to assist students in game development

As displayed in figure 5, most participants of this study, $89 \%$, had positive attitude towards the idea that games can be used to study a subject matter collaboratively. Only $9 \%$ disagreed and $2 \%$ of them strongly disagreed.

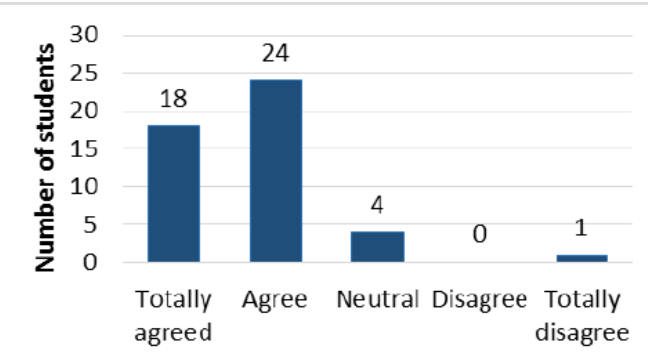

Figure 5. Students' opinions about whether games can be used to study a subject matter collaboratively

Figure 6 shows students' response for the question whether students are interested in creating a game with different topics, one fifth of the respondents reported that they were very interested and $49 \%$ said they were interested in creating more games with different topics. Less than one fifth, $17 \%$, answered neutral, and the remaining, $13 \%$, said not interested.

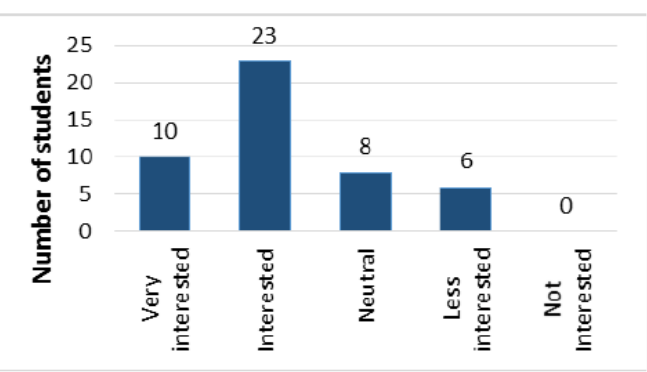

Figure 6. Students' opinions about their interest in creating a game with different topics

Statements shown in figure 7 found out whether the participants were excited for making games collaboratively. The findings show that $30 \%$ of the respondents felt very excited and $40 \%$ of respondents felt excited. $28 \%$ of them said they felt ambivalent. Only $2 \%$ responded less excited.

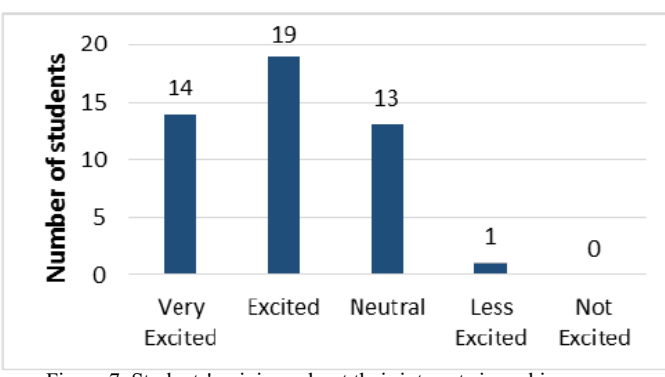

Figure 7. Students' opinions about their interests in making games collaboratively

When asked whether the need to learn a subject matter is fulfilled by developing a game, one tenth of the respondents strongly agreed. More than half of them said that the need was met. $34 \%$ said they felt neutral. Only $2 \%$ of the respondents disagreed that the game met their needs to learn a subject.

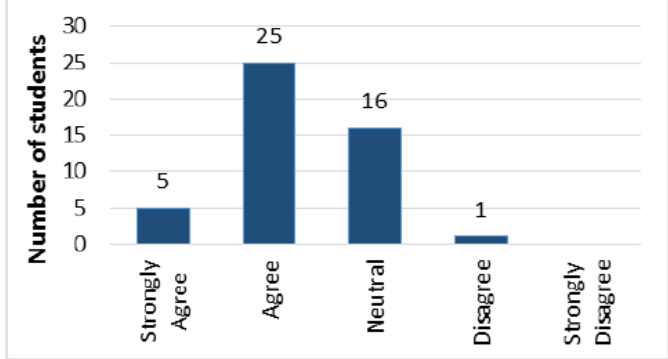

Figure 8. Students' opinions about whether a game meets their needs for learning a subject

Figure 9 shows the responses concering whether respondents liked creating a game collaboratively. $15 \%$ of 
2016 International Seminar on Application for Technology of Information and Communication

respondents were very interested and $49 \%$ of respondents were interested in making games. While $23 \%$ of respondents responded if they taught how to develop the game for learn together is mediocre, and $13 \%$ responded the less interested.

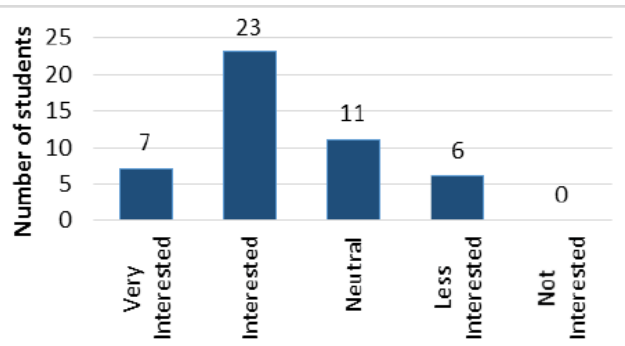

Figure 9. Students' opinions about interest in creating a games for collaborative activities

$17 \%$ of respondents were very interested and $53 \%$ of respondents were interested to share the games that they created for others. However, $26 \%$ of respondents said that they were ambivalent, and $2 \%$ were not interested.

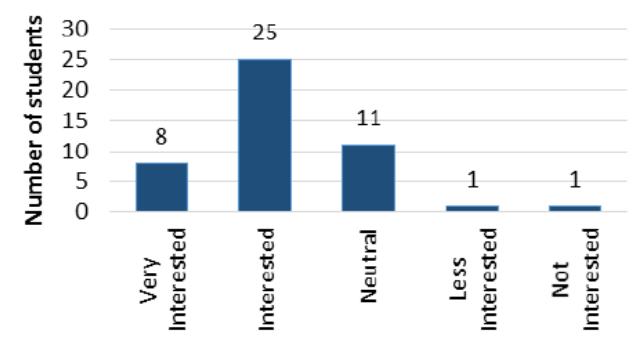

Figure 10. Students' opinions about interest to share games that they have been made to others

When asked about the usefulness of the game they created for other learners, $17 \%$ of respondents said it was very useful, $47 \%$ responded that it was useful. Thus, more than half of them showed positive attitude towards the inquiry. $32 \%$ of them said they were neutral and only $4 \%$ felt that the game was not useful for other learners. .

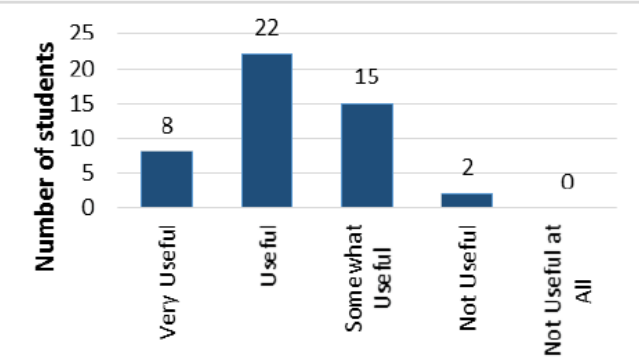

Figure 11. Students' opinions about whether the game they created could be used by others
Figure 12 shows the responses for when asked whether they agreed if the game could be played on a tablet or smartphone. More than $80 \%$ of the respondents said they agreed. . One tenth of them said they were ambivalent.

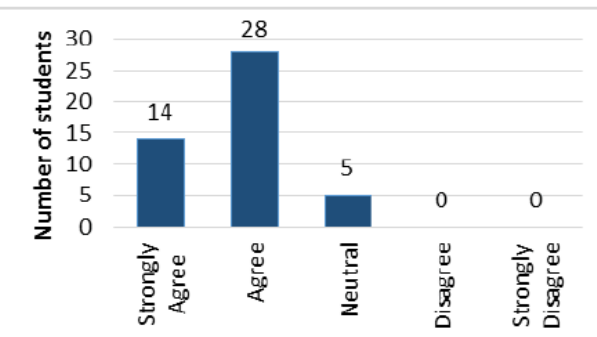

Figure 12. Students' opinions about whether a game could be played on a tablet or a smartphone

Figure 13 shows students' responses when asked whether the use of cartoon characters in the game is an attractive idea. It is described in the figure that almost all respondents expressed positive attitude toward the use of cartoon characters in a game $(89 \%)$. The remaining $11 \%$ said they were ambivalent about the question.

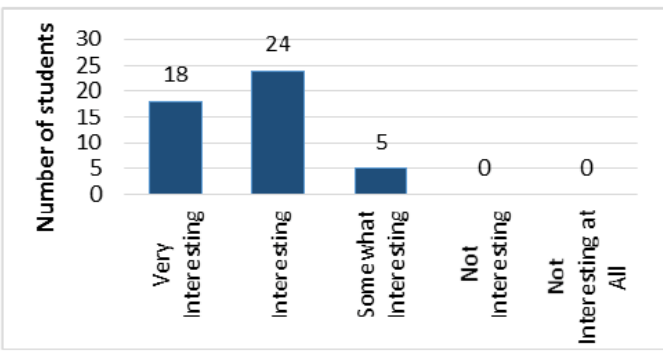

Figure 13. Students' opinions about the attractiveness of the cartoon characters in the game

Respondents were asked whether the game they created was interesting. Figure 14 shows the results of this question. The figure presents that $21 \%$ of respondents said it was very interesting, $60 \%$ responded that it was interesting. $19 \%$ of them said they were neutral about it.

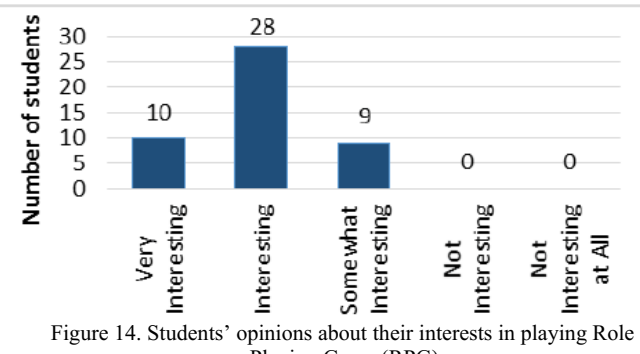

Playing Game (RPG) 
In response to the final survey question, three fourths of the respondents said they were interested to learn how to create different kinds of games, while the rest had more negative attitudes towards the statement.

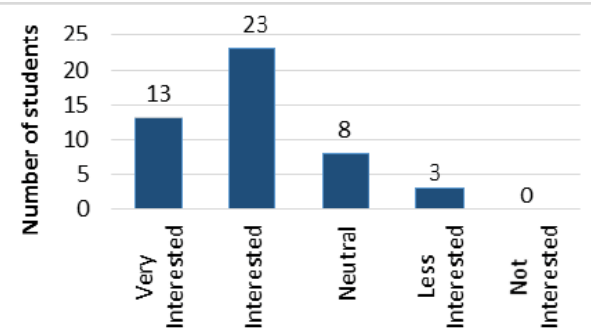

Figure 15. Students' opinions about their interests to learn how to create different kinds of game

In the third part, the open ended questions, the reseachers asked about the challenges of creating the games, the weaknesses of the game, and the kinds of games students perceive would work for collaborative learning strategies. The data indicate that students' difficulties were more related to the technical issues and their familiarity with game making. Students stated that the games would have been more attractive if the characters and the maps had been more varied. Games such as SIMS or Harvest Moon could be some of the options that are feasible to be implemented in collaborative learning classroom.

\section{CONCLUSION}

The findings of the study indicated that students who are not majoring in computer science or not familiar with game design can create a simple game for collaborative learning. Most respondents showed positive attitude towards the use of games to learn a subject matter collaboratively. The findings revealed positive attitude towards the task of creating games for classroom use. With $45 \%$ said very happy and $38 \%$ said happy, they believed the use of games will make learning become more fun. They were very excited about creating questions for the role play. It's proved with respondents said 55\% excited and $26 \%$ very excited.

Ready-to-use template was helpful since they could easily modify the games. In other words, the template provides a solid basis for students to start developing the game. Even though a few students had difficulties with the technical aspects of creating a game, they viewed the task as very interesting and useful for them. This is understandable because participants are non-computer major. Respondents said they were confident that the use of games will help them learn materials better and eventually make them better learners.

\section{ACKNOWLEDGMENT}

This paper is a part of a research project funded by the Indonesian Directorate General of Higher Education in the year 2016 under the scheme of International Collaboration and Publication grant.

\section{REFERENCES}

[1] E. Lehtinen, K. Hakkarainen, L. Lipponen, M. Rahikainen, and H. Mukkkonen, "Computer supported collaborative learning: A review,"JHGI Giesbers Reports Educ., pp. 1-58, 1999.

[2] N. Suryani, "Implementasi Model Pembelajaran Kolaboratif untuk Meningkatkan Ketrampilan Sosial Siswa," J. Soc. Sci. 2008 .

[3] Government of Republic of Indonesia, Act of the Republic of Indonesia, number 20 , year 2003 , on national education syst no. 20. Indonesian: lanipolis.iiep.unesco.org, 2003, pp. 1-58.

[4] Sudarman, "Penerapan Metode Collaborative Learning untuk Meningkatkan Pemahaman Materi Mata Kuliah Metodologi Penelitian,”J. Soc. Sci., vol. 3, no. 1, pp. 94-100, 2003.

[5] G. Stahl, T. Koschmann, and D. Suthers, "Computer-supported collaborative learning: An historical perspective," Cambridge Handb. Learn. Sci., no. 2006, pp. 409-426, 2006.

[6] M. Papastergiou, "Online Computer Games as Collaborative Learning Environments: Prospects and Challenges for Tertiary Education," J. Educ. Technol. Syst., vol. 37, no. 1, pp. 19-38, 2008.

[7] D. Schaffhauser, "Will Gaming Save Education , or Just Waste Tim??,"THE Journal, pp. 1-5, 2013.

[8] Erwin, "2016, Indonesia Empat Besar Pengguna Smartphone," koran.tempo.co, 2015. [Online]. Available: http://koran.tempo.co/konten/2015/01/24/363157/2016Indonesia-Empat-Besar-Pengguna-Smartphone. [Accessed: 01Jan-2016].

[9] R. Sanjaya, A. E. M. Soekesi, and A. P. S. Sitohang, "Technology entrepreneurship model development for teachers," Int.J.Technoentrepreneurship, vol. 3, no. 1, pp. 60-66, 2015

[10] X. H. X. He and W. H. W. Hu, "An Innovative Web-Based X. H. X. He and W. H. W. Hu, "An Innovative Web-Based
Collaborative Learning Model and Application Structure," in 2008 International Conference on Computer Science ar Software Engineering, 2008, vol. 5, pp. 56-59.

[11] D. B. Clark, E. E. Tanner-smith, and S. Killingsworth, "Digital Games for Learning : A Systematic Review and Meta-Analysis Preliminary Meta-Analysis Results," 2015.

[12] P. Backlund and M. Hendrix, "Educational games-are they worth the effort? A literature survey of the effectiveness of serious games," Games Virtual Worlds Serious Appl. 2013 5th Int. Conf. no. December, 2013.

[13] K.-Y. Liu, C.-T. Yang, and K.-H. Chang, "Development of a multiplayer online role-playing game-based learning system for multiple curriculums," in Digital Game and Intelligent Toy Enhanced Learning (DIGITEL), 2012 IEEE Fourth International Conference on, 2012, pp. 62-66.

[14] Kappa Delta Pi, John Dewey Experience \& Education, Touchstone. New York: Simon \& Schuster Inc., 1997.

[15] T. Rostitawati, "Konsep pendidikan john dewey," J. Manaj. Pendidik. Islam, vol. 02, pp. 133-139, 2014

[16] A. T. Putra, "Tujuan Pendidikan," Academia.edu, 2010. [Online]. Available:

https://www.academia.edu/4563266/MAKALAH TUJUAN_PE NDIDIKAN. [Accessed: 04-Feb-2016].

[17] J. R. Abanador, G. C. D. Buesa, G. M. L, and J. Mañibo, "Teaching Methods and Learning Preferences in the Engineering Department of an Asian University," Int. J. Acad. Res. Progress. Department of an Asian University," Int.

[18] S. A. Kalaian and R. M. Kasim, "A Meta-analytic Review of Studies of the Effectiveness of Small- Group Learning Methods on Statistics Achievement," J. Stat. Educ., vol. 22, no. 1, pp. 120,2014

[19] M. Dooly, "Constructing Knowledge Together," Telecollaborative Lang. Learn. A Guideb. to Moderatin Intercult Collab Online pp. 21-45,2008.

[20] B. L. Smith and J. MacGregor, "What is Collaborative Learning?," Collab. Learn. A Sourceb. High. Educ., pp. 1-11, 1992 
LEMBAR

\section{HASIL PENILAIAN SEJAWAT SEBIDANG ATAU PEER REVIEW KARYA ILMIAH : PROSIDING}

Judul Karya Ilmiah (paper) : Developing Educational Game for Collaborative Learning

Nama Penulis

Jumlah Penulis

Status Pengusul

Identitas Prosiding
: Aprilia Christianti, Ridwan Sanjaya, Cecilia Titiek Murniati : 3 orang : penulis pertama/penulis ke 3/penulis korespondensi* : a. Judul Prosiding

b. ISSN/ISBN

c. Tahun Terbit/Tempat Pelaksanaan

d. Penerbit/organiser

e. Alamat repository PT/web Prosiding :

https://ieeexplore.ieee.org/doc ument/7873800

f. Terindeks di (jika ada)

Kategori Publikasi Makalah (beri Vpada kategori yang tepat)

$\square$ Prosiding Forum IImiah Internasional

$\square$ Prosiding Forum IImiah Nasional

Hasil Penilaian Peer Review :

\begin{tabular}{|l|c|c|c|}
\hline \multirow{2}{*}{ Komponen yang dinilai } & Nilai Maksimal Prosiding & Nilai Akhir yang \\
& $\begin{array}{c}\text { International } \\
\text { Diperoleh }\end{array}$ & $\begin{array}{c}\text { Nasional } \\
\square\end{array}$ & 0.3 \\
\hline a. Kelengkapan unsur isi paper (10\%) & 0,3 & & 0.7 \\
\hline $\begin{array}{l}\text { b. Ruang lingkup dan kedalaman } \\
\text { pembahasan (30\%) }\end{array}$ & 0,9 & & 0.7 \\
\hline $\begin{array}{l}\text { c. Kecukupan dan kemutakhiran data } \\
\text { /informasi dan metodologi (30\%) }\end{array}$ & 0,9 & & 0.9 \\
\hline $\begin{array}{l}\text { d. Kelengkapan unsur dan kualitas } \\
\text { terbitan/prosiding (30\%) }\end{array}$ & 0,9 & & 2.6 \\
\hline Total =100\% & 3 & & 0.9 \\
\hline Nilai Pengusul & 3 & & 0.9 \\
\hline
\end{tabular}

Catatan penilaian paper oleh Reviewer 1 :

Penelition in mengunghog pentingnya Kalaboras dalan prases pempelajirng mengunaken perangliat telenolig pernbelajaran. Pendeliatan sepert in perlu mindapat perbahios byji dari para pinsidik das peygumbil kebijakes penchorkes.

14 Maret 2019

Reviewer 1,

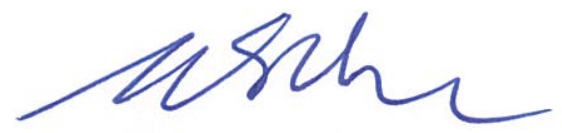

Nama

: Prof. Dr. Gusti Astika, M.A

NIP/NIDN

Unit Kerja

: 1983025/0614065101

Jabatan Fungsional

: Fakultas Bahasa dan Seni Universitas Kristen Satya Wacana

Bidang IImu

: Guru Besar

: Linguistik 
LEMBAR

HASIL PENILAIAN SEJAWAT SEBIDANG ATAU PEER REVIEW KARYA ILMIAH : PROSIDING

Judul Karya Ilmiah (paper) : Developing Educational Game for Collaborative Learning

Nama Penulis

Jumlah Penulis

Status Pengusul

Identitas Prosiding
: Aprilia Christianti, Ridwan Sanjaya, Cecilia Titiek Murniati

: 3 orang

: penulis pertama/penulis ke 3/penulis korespondensi*

a. Judul Prosiding
: 2016 Seminar on

Application for

Technology of Information and Communication

b. ISSN/ISBN

: 978-1-5090-2326-4

c. Tahun Terbit/Tempat Pelaksanaan

d. Penerbit/organiser

: 2017/ Semarang

: IEEE/ Universitas Dian Nuswantoro

e. Alamat repository PT/web Prosiding :

https://ieeexplore.ieee.org/doc ument/7873800

f. Terindeks di (jika ada) :-

Kategori Publikasi Makalah (beri Vpada kategori yang tepat)

\section{$\square$ Prosiding Forum IImiah Internasional}

$\square$ Prosiding Forum IImiah Nasional

Hasil Penilaian Peer Review:

\begin{tabular}{|l|c|c|c|}
\hline \multirow{2}{*}{ Komponen yang dinilai } & \multicolumn{2}{|c|}{ Nilai Maksimal Prosiding } & Nilai Akhir yang \\
\cline { 2 - 3 } & $\begin{array}{c}\text { Internatipnal } \\
\text { Diperoleh }\end{array}$ & $\begin{array}{c}\text { Nasional } \\
\square\end{array}$ & 0.3 \\
\hline a. Kelengkapan unsur isi paper (10\%) & 0,3 & & $0 \cdot 6$ \\
\hline $\begin{array}{l}\text { b. Ruang lingkup dan kedalaman } \\
\text { pembahasan (30\%) }\end{array}$ & 0,9 & & $0 \cdot 6$ \\
\hline $\begin{array}{l}\text { c. Kecukupan dan kemutakhiran data } \\
\text { /informasi dan metodologi (30\%) }\end{array}$ & 0,9 & 0,9 & 9 \\
\hline $\begin{array}{l}\text { d. Kelengkapan unsur dan kualitas } \\
\text { terbitan/prosiding (30\%) }\end{array}$ & 3 & & 2.4 \\
\hline Total =100\% & 3 & & \\
\hline Nilai Pengusul & 0.9 & \\
\hline
\end{tabular}

Catatan penilaian paper oleh Reviewer $2 \mathrm{~d}$ :

$$
\text { tehnologi dalan pembelajaran. }
$$

14 Maret 2019

Reviewer 2,

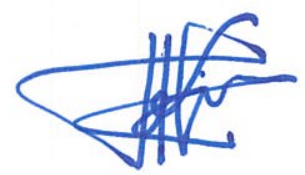

Nama

: Dr. Katarina Rustipa M.Pd

NIP/NIDN

: YB.2.01.03.00/0628086301

Unit Kerja

: Fakultas Bahasa dan IImu Budaya Universitas Stikubank Semarang

Jabatan Fungsional

: Lektor Kepala

Bidang IImu

: Applied Linguistics

*Coret yang tidak perlu 
LEMBAR

HASIL PENILAIAN SEJAWAT SEBIDANG ATAU PEER REVIEW

KARYA ILMIAH : PROSIDING

Judul Karya Ilmiah (paper) : Developing Educational Game for Collaborative Learning

Nama Penulis

Jumlah Penulis

Status Pengusu

Identitas Prosiding
: Aprilia Christianti, Ridwan Sanjaya, Cecilia Titiek Murniati

: 3 orang

: penulis pertama/penulis ke 3 /penulis korespondensi*

a. Judul Prosiding

b. Nomor ISSN/ISBN

c. Tahun Terbit/Tempat Pelaksanaan

d. Penerbit/organiser

e. Alamat repository PT/web Prosiding

https://ieeexplore.ieee.org/doc ument/787380

f. Terindeks di (jika ada)

Kategori Publikasi Makalah (beri Vpada kategori yang tepat)

$\square$ Prosiding Forum IImiah Internasional

$\square$ Prosiding Forum Ilmiah Nasional

Hasil Penilaian Peer Review :

\begin{tabular}{|c|c|c|c|c|}
\hline \multirow[b]{2}{*}{ Komponen yang dinilai } & \multicolumn{2}{|c|}{ Nilai Maksimal Prosiding } & \multicolumn{2}{|c|}{ Nilai Akhir yang Diperoleh } \\
\hline & $\stackrel{\text { International }}{\square}$ & $\begin{array}{c}\text { Nasional } \\
\square\end{array}$ & $\begin{array}{l}\text { Reviewer } \\
\text { PTS }\end{array}$ & $\begin{array}{c}\text { Tim PAK } \\
\text { Kopertis Wil } \\
\text { VI. }\end{array}$ \\
\hline a. Kelengkapan unsur isi paper (10\%) & 0,3 & & 0,25 & \\
\hline $\begin{array}{l}\text { b. Ruang lingkup dan kedalaman } \\
\text { pembahasan }(30 \%)\end{array}$ & 0,9 & & $0 / 75$ & \\
\hline $\begin{array}{l}\text { c. Kecukupan dan kemutakhiran data } \\
\text { /informasi dan metodologi (30\%) }\end{array}$ & 0,9 & & 0,75 & \\
\hline $\begin{array}{l}\text { d. Kelengkapan unsur dan kualitas } \\
\text { terbitan/prosiding (30\%) }\end{array}$ & 0,9 & & 0175 & \\
\hline Total $=100 \%$ & 3 & & 215 & \\
\hline Nilai Pengusul & 3 & & 2,5 & \\
\hline \multicolumn{5}{|c|}{ Catatan penilaian paper oleh Tim PAK Kopertis Wilayah VI : } \\
\hline
\end{tabular}

Tim PAK, 